\title{
Impact of Credit Risk on the Profitability of Selected Commercial Banks Listed on the National Stock Exchange
}

\author{
1Dr.Sitaram Pandey \\ ${ }^{2}$ Dr. Amitava Samanta
}

\begin{abstract}
This research is focusing on evaluation of the impact of credit risk on the profitability of selected commercial banks listed on National Stock Exchange. The financial ratios are taken as a proxy to evaluate credit risk and bank's profitability. Profitability was measured through Return on Equity and Return on Assets whereas credit risk was measured by Pre-Provision Profit to Total Loans and Advances, Loan to Asset Ratio, Capital Adequacy Ratio, Credit to Deposit Ratio and Advances over Loan Funds. Based on the financial information of 2009 to 2017, the study concludes that Credit risk, as calculated from Pre-Provision Profit to Total Loans and Advances, Loan to Asset Ratio, Capital Adequacy Ratio, Credit to Deposit Ratio and Advances over Loan Funds have a non-significant relationship with profitability measured by Return on Assets whereas there is significant relationship exist only between Advances over Loan Funds and profitability measured by Return on Equity. The regression model of ROE shows the model is significant as compared to ROA model. The present study employed Auto Correlation and Durbin-Watson statistics, Unit root test \& Multi-Collinearity tests to measure the robustness of time series data. Also the results of the regression analysis show that there exist a negative correlation between credit upon deposit ratio and return on equity. As per the current study, the Indian banks has to keep check on advances upon total funds ratio, as it was found most significant factor impacting the profitability of Indian banks.
\end{abstract}

Keywords - Credit risk, profitability, banks, return on equity, return on assets

Corresponding Author : ${ }^{1}$ Assistant Professor, University Department of Manangement, Vinoba Bhave University, Hazaribagh, Jharkhand. Phone no. 07858882626, Mail Id: spandey1203@gmail.com

2 Assistant Professor, University Department of Commerce \& Management, Vinoba 
Bhave University, Hazaribag, Jharkhand. Phone Number : 09431795999, Email ID : dramitava1@yahoo.com

\section{Introduction}

The banking system of any country plays a vital role in its economic development. It acts like a backbone for all the economic activities related to individual, organization, government or foreign institutions. Any economy cannot afford failure of a banking system as its affect would be irreparable. The banking industry in the India supports the world most growing economy with the greatest diversity in banking institutions. The banking industry has awakened to risk management, especially after the global crisis of 2007-08 and failure of banks like Lehman brothers. So, today risk assessment plays an important role in the activity of financial institutions. For effective risk management, correct risk assessment is essential and effective risk management is necessary for the success and perpetuity of business activity. In banking system, the risk management is very important to avoid financial losses which will affect the returns and sentiments of depositors and investors. There are many types of risks attached with the banking system but the most prominent of them are credit risk, market risk, operational risk, liquidity risk, reputational risk, business risk, systematic risk and interest rate risk. Out of all these risks, the major cause of banks problems are related to credit risks so its management is essential for banks.

According to BIS, credit risk is defined as the potential that a bank borrower or counterparty will fail to meet its obligations in accordance with agreed terms. Credit risk is most likely caused by loans, acceptances, interbank transactions, trade financing, foreign exchange transactions, financial futures, swaps, bonds, equities, options etc [1]. Credit risk arises when a debtor was unable to pay its obligations or it's financial capacity aggravated resulted in an economic loss to the bank. Banks are facing credit risk also when they trade various other financial instruments including: interbank transactions, exchange rate transactions, future, swaps and options contracts.

In this paper, we are covering credit risk management to assess its impact on profitability of some selected commercial banks. Little research exists on the credit risk management in India apart from some research studies on theoretical framework of credit risk management. This paper seeks to contribute to the existing body of work in this area by examining 
the extent to which credit risk management impact to financial performance of some NSE listed banking companies. The rest of the paper is structured as follows: the next section reviews the existing work on credit risk management and its effect on financial performance of the banking companies across the countries. Section 3 provides a brief description of objectives and hypothesis. Section 4 presents research methodology and specifies the estimation models used in the study. Section 5 the data employed for the empirical analysis of data and interpretation of results. The final section 6 summarizes the findings and draws out some conclusions.

\section{Literature Review}

Poudel (2012) [2] studied the impact of credit risk management on financial performance of commercial banks in Nepal and revealed that parameters like default rate, cost per loan assets and capital adequacy ratio have an inverse impact on banks' financial performance; however , the default rate is the most reliable predictor of bank financial performance and advised banks to design and formulate strategies that will not only minimize the exposure of the banks to credit risk but will enhance profitability.

Adekunle et al. (2015) [3] examined Credit Risk Management and Financial Performance of Selected Commercial Banks in Nigeria. The results revealed that credit risk management has significant effect on financial performance of commercial banks and further recommend that maintaining a minimum level of non-performing loans vis-à-vis provision for loans and advances will enhance financial performance through its positive effect on return on equity.

Alshatti (2015) [4] in his paper " The effect of credit risk management on financial performance of the Jordanian commercial banks" examined the effect of credit risk management on financial performance of the Jordanian commercial banks during the period (2005-2013) and concluded that the credit risk management indicators considered in his research have a significant effect on financial performance of the Jordanian commercial banks.

Karugu \& Ntoiti (2015) [5] analyzed the effect of Credit Risk Management Practices on Profitability of Listed Commercial Banks at Nairobi 
Securities Exchange in Kenya. The results indicated that credit risk governance had a positive and significant effect on profitability and also concluded that credit appraisal, debt collection and credit risk governance have a significant positive effect on profitability.

Makori (2015) [6] studied the effects Of Credit Risk Management Practices on Profitability of Deposit Taking SACCOs in Nairobi County. Through the findings he concluded that credit appraisal practices, credit monitoring, debt collection practices and credit risk governance practices have a positive effect on the financial profitability of the SACCOs. The study also concluded that effective credit risk management policy maximize a financial sector's risk adjusted return by maintaining credit exposure within acceptable limits.

Muhamet. \& Arbana (2016) [7] in his research paper studied the Effect of Credit Risk Management on Banks' Profitability in Kosovo. The output showed a substantial relation between the variables and reflected that a higher risk asset ratio would result in a marginal decline in profitability while higher nonperforming loans had a positive and more substantial effect. Further analysis showed a predominantly negative effect, highlighting the possible inadequacy of the multivariate model.

Ndoka \& Islami (2016) [8] in his paper "The Impact of Credit Risk Management in the Profitability of Albanian Commercial Banks During the Period 2005-2015 " has studied the Albanian banking problems related to credit risk. This study provides a contribution within the identification of credit risk factors that affect more the profitability of the Albanian banks and found a scientific solution in order to manage the credit risk in a more efficient way.

Annor \& Obeng (2017) [9] studied the Impact of Credit Risk Management on the Profitability of Selected Commercial Banks Listed on the Ghana Stock Exchange. The study employed the Random Effect Model within the panel estimation technique framework. Their findings showed that indeed credit risk management have a significant relationship with the profitability of banks. Their study recommends that banks should assess and manage credit risk indicators vigorously in order to reduce their exposure to these risks.

Kutum (2017) [10] has analyzed the impact of credit risk on the 
profitability of five banks of Palestine Exchange. He found a weak but positive relationship between credit risk measured by non-performing loans to total loans and advances and profitability as measured by return on assets. In his study, also he founds that bank size was positively related to profitability.

Ishak et al. (2018) [11] has done the research on credit risk management of bank listed on Bursa Malaysia and concluded that , most of the credit risk management indicators have a negative impact on profitability of banks. The regression model of ROE shows the model is significance as compared to ROA model.

\section{Research Objectives \& Hypotheses}

\section{a. Objectives}

To identify the impact of credit risk management on profitability of Indian commercial banks.

\section{b. Hypotheses}

H0 : Credit risk has no significant relationship with profitability of banks listed on the national stock exchange.

H1 : Credit risk has significant relationship with profitability of banks listed on the national stock exchange.

\section{4. .Research Methodology}

The present study employed Auto Correlation and Durbin-Watson statistics, Unit root test \& Multi- collinearity tests to measure the robustness of time series data. A brief description of these tests is provided in this section.

\section{a. Research Design}

The research is an exploratory study into the relationship between credit risk and the profitability of banks listed on the National Stock Exchange.

\section{b. Sample}

The study uses data from the financial statements of six commercial 
banks three from public sector bank and three from private sector bank from 2009-2017. All the banks are listed in National stock exchange. The banks are as follows: State Bank of India (SBI), Punjab National Bank (PNB), Bank of India (BOI), HDFC Bank, ICICI Bank, Axis Bank.. The secondary data has been used in this research.

\section{c. Data Collection}

The data was collected in order to establish the relationship (if any) between credit risk and profitability. The profitability of the banks is represented by Return on Equity (ROE) and Return of Assets. These two will serve as dependent variables. The independent variables that will measure credit risk are pre-provision profit over total loans and advances, loan to asset ratio, capital adequacy ratio, advances over loan funds and credit upon deposit ratio.

\subsection{Test of Multicollinearity}

Variance Inflation Factors (VIFs) are a method of measuring the level of co linearity between the regressors in an equation. VIFs show how much of the variance of a coefficient estimate of a regressor has been inflated due to collinearity with the other regressors. There are two forms of the Variance Inflation Factor: centered and uncentered. The centered VIF is the ratio of the variance of the coefficient estimate from the original equation divided by the variance from a coefficient estimate from an equation with only that regressor and a constant. The uncentered VIF is the ratio of the variance of the coefficient estimate from the original equation divided by the variance from a coefficient estimate from an equation with only one regressor (and no constant).

\subsection{Auto Correlation and Durbin-Watson statistics}

The serial autocorrelation is used to test the relationship between the time series its own values at different lags. If the serial autocorrelation is negative it means it is mean reverting and accepts the null hypothesis and if the result is positive coefficients then it rejects the null hypothesis. The technique that is used here is Durbin-Watson statistics. The Durbin Watson statistic is a number that tests for autocorrelation in the residuals from a statistical regression analysis. The Durbin-Watson statistic is always between 0 and 4 . A value of 2 means that there is no 
auto correlation in the sample.

\subsection{Unit Root Tests}

Unit root tests are commonly used to test the stationary property of a time series data. In this study two different unit root tests are employed to test the null hypothesis of a unit root. These tests are the Augmented Dickey-Fuller (ADF) test \& the Phillips-Perron (PP) test. We subject each time series to a check for stationarity. The ADF test was employed to time series of pre- provision profit over total loans and advances, loan to asset ratio, capital adequacy ratio, advances over loan funds and credit upon deposit ratio, return of equity and return of asset series.

\subsection{The Regression Model}

The study uses a general linear model of regression to establish the relationship between the independent and the dependent variables. Here return of equity as a dependent variable and return of asset as a dependent variable will be separately regressed with the independent factors.

Table1: Definition of Variables

\begin{tabular}{|l|l|l|}
\hline Variable & Definition & Expected result \\
\hline ROE & $\begin{array}{l}\text { Profitability = Return on } \\
\text { Equity = Net Income/ } \\
\text { Total Equity }\end{array}$ & \\
\hline ROA & $\begin{array}{l}\text { Profitability = Return on } \\
\text { Assets = Net Income/ } \\
\text { Total Assets }\end{array}$ & - \\
\hline PTLA & $\begin{array}{l}\text { Credit Risk = Pre- } \\
\text { Provision Profit / Total } \\
\text { Loans and Advances }\end{array}$ & Increase/Decrease \\
\hline LAR & $\begin{array}{l}\text { Credit Risk = Loan to } \\
\text { Asset ratio }\end{array}$ & Increase/Decrease \\
\hline CAR & Credit Risk = Capital & Increase/Decrease \\
\hline
\end{tabular}




\begin{tabular}{|l|l|l|}
\hline & Adequacy Ratio & \\
\hline ALF & $\begin{array}{l}\text { Credit Risk = Advances } \\
\text { over Loan Funds }\end{array}$ & Increase/Decrease \\
\hline CDR & $\begin{array}{l}\text { Credit Risk = Credit } \\
\text { upon Deposit ratio }\end{array}$ & Increase/Decrease \\
\hline
\end{tabular}

The dependent variables in the models are Return on Equity and Return of Assets. These variables are proxy of profitability whereas proxy of credit risk are pre-provision profit over total loans and advances, loan to asset ratio, capital adequacy ratio, advances over loan funds and credit upon deposit ratio.

\section{Results \& Discussions}

\subsection{Descriptive Statistics}

\section{Table 2: Descriptive Statistics of Variables}

\begin{tabular}{|l|l|l|l|l|l|l|l|}
\hline VARIABLE & Mean & S.D. & Kurtosis & Skewness & Minimum & Maximum & Count \\
\hline ROE & 5.752 & 12.51 & 2.41 & -1.62 & -32.85 & 19.5 & 60 \\
\hline ROA & 275.61 & 152.96 & 4.81 & 2.11 & 138.72 & 813.47 & 60 \\
\hline PTLA & 2.466 & 0.796 & -1.335 & -0.249 & 0.98 & 3.56 & 60 \\
\hline LAR & 0.125 & 0.013 & -1.065 & 0.337 & 0.11 & 0.15 & 60 \\
\hline CAR & 14.055 & 2.460 & -0.970 & -0.057 & 9.2 & 18.42 & 60 \\
\hline ALF & 74.712 & 6.365 & 0.0749 & -0.694 & 59.69 & 84.82 & 60 \\
\hline CDR & 83.332 & 10.456 & -0.329 & 0.483 & 66.72 & 105.08 & 60 \\
\hline
\end{tabular}

Source: Author's own source based on collected data

Table 2 above shows the descriptive statistics of the data gathered from the 
banks. It can be observed that the average return on equity is $5.752 \%$ while the average return of assets is $275.61 \%$. The average rate on pre-provision profit over total loans and advances is $2.466 \%$ whereas average rate of loan to asset ratio is $12.5 \%$ which indicates a low level of credit risk and mean of capital adequacy ratio is 14.05 . Similarly, the average rate of advances over loan funds is $74.71 \%$ and the average rate of credit upon deposit ratio is $83.33 \%$.

The standard deviation is highest in return of assets. Data of all the variables except ROA are platykurtic. Some variables are right skewed whereas some are left skewed.

\subsection{Test for Multicollinearity}

Table 3: Test for Multicollinearity

\begin{tabular}{|l|c|}
\hline Variables & Centered VIF \\
\hline PTLA & 6.146 \\
\hline LAR & 2.688 \\
\hline CAR & 4.785 \\
\hline ALF & 2.352 \\
\hline CDR & 3.518 \\
\hline
\end{tabular}

Source: Author's own source based on collected data

In order to check multicollinearity among the factors or independent variables, the study uses the test of coefficient diagnostics and calculated the values of Coefficient Variance and Uncentered Variance Inflation Factors (VIF) and Centered VIF. The results as shown in Table 3 above show the value of the Centered VIF values for both independent variables ROA \& ROE. The multicollinearity does not exist in the data as none of the VIF values for independent variables is higher than 10.

\subsection{Test for Autocorrelation}


This evaluation is needed to test for the presence or otherwise of first-order serial correlation (autocorrelation) in the independent variables. That is, it is used to determine whether or not the value of each variable (in this case factors of credit risk measure) in one period, $t$, depends on its value in another period $\mathrm{t}-1$. The measurement of autocorrelation was done through Durbin- Watson statistic. From the regression results, computed value of Durbin-Watson statistic is around 2, which shows that there is no evidence of positive first-order serial correlation. Hence, there is no autocorrelation in credit risk variables. So, it is concluded that the values of the respective credit risk variables in one period did not depend on their values in another period.

\subsection{Unit Root Tests}

All estimations in this study are done using E-Views. The result of unit root test is shown in Table 4. All the series are stationary at logarithmic first difference \& they are significant at $1 \%$ level as $\mathrm{p}$ value is less than 0.05 . Hence, the null hypothesis that the series has unit root was rejected. So, series are stationary at I(1).

Table 4: The results of unit root tests

\begin{tabular}{|c|c|c|c|}
\hline Variables & $\begin{array}{c}\text { ADF } \\
\text { Statistics }\end{array}$ & P-Value & $\begin{array}{c}\text { Order of } \\
\text { Integration }\end{array}$ \\
\hline PTLA & -5.987 & 0.0000 & I (1) \\
\hline LAR & -5.629 & 0.0001 & I (1) \\
\hline CAR & -7.461 & 0.0000 & I (1) \\
\hline ALF & -6.225 & 0.0000 & I (1) \\
\hline CDR & -4.603 & 0.0010 & I (1) \\
\hline
\end{tabular}

Source: Author's own source based on collected data 


\subsection{Regression Analysis}

The results of the regression are shown below in table 5 .

Table 5 : Model Summary of Regression

\begin{tabular}{|l|l|l|l|l|}
\hline Model & $\mathbf{R}$ & $\mathbf{R}$ Square & $\begin{array}{l}\text { Adjusted R } \\
\text { Square }\end{array}$ & $\begin{array}{l}\text { Std. Error of } \\
\text { the Estimate }\end{array}$ \\
\hline 1 (ROA) & $0.2088^{\mathrm{a}}$ & 0.0436 & -0.15564 & 164.438 \\
\hline $2 .(\mathrm{ROE})$ & $0.8672^{\mathrm{a}}$ & 0.7520 & 0.700423 & 6.8483 \\
\hline
\end{tabular}

Source: Author's own source based on collected data

a. Predictors : (constant) and dependent variables are pre-provision profit over total loans and advances, loan to asset ratio, capital adequacy ratio, advances over loan funds and credit upon deposit ratio. Model 1 represents variable return on asset and Model 2 represents variable return on equity.

The $\mathrm{R}$ square value of 0.0436 shown in Model 1 of Table 5 above shows that only $4.36 \%$ of the variation in the dependent variable, Return on Assets, can be explained by variations in the dependent variable. The $\mathrm{R}$ Square of 0.7520 for model 2 shows that $75.20 \%$ of the variations of the dependent variable, Return of Equity, can be explained by variations in the dependent variable. So, the return of asset is poorly explained by dependent variables whereas return of equity is good enough explained by selected dependent variables.

Table 6 : Analysis of Variance a,b

\begin{tabular}{|l|l|l|l|l|l|}
\hline $\begin{array}{l}\text { Dependent } \\
\text { Variables }\end{array}$ & Model & $\begin{array}{l}\text { Sum of } \\
\text { Squares }\end{array}$ & Mean Square & F & $\begin{array}{l}\text { Significance } \\
\text { F }\end{array}$ \\
\hline $\begin{array}{l}\text { Return } \\
\text { on Assets }\end{array}$ & Regression & 29588.74 & 5917.749 & 0.218851 & $0.9509^{\mathrm{a}}$ \\
\cline { 2 - 6 } & Residual & 648961.6 & 27040.07 & & \\
\cline { 2 - 6 } & Total & 678550.3 & & & \\
\hline $\begin{array}{l}\text { Return on } \\
\text { Equity }\end{array}$ & \begin{tabular}{l} 
Regression \\
\cline { 2 - 6 }
\end{tabular} & 3414.435 & 682.887 & 14.560 & $0.00000^{\mathrm{b}}$ \\
\hline
\end{tabular}




\begin{tabular}{|l|l|l|l|l|}
\hline Total & 4540.026 & & & \\
\hline
\end{tabular}

a.Dependent Variable : Return on Assets

b.Dependent Variable : Return on Equity

Source: Author's own source based on collected data

For Model 1, the p-value (significance F) of 0.9509 is far greater than 0.05 which shows that overall the model does not predict the dependent variable of return on asset well. However, the p-value of Model 2 shows that the model predicts the dependent variable of return on equity well. Thus, Model 2 fits well in this research.

Table 7: Coefficients

\begin{tabular}{|l|l|l|l|l|l|l|}
\hline Variables & \multicolumn{5}{l}{ ROA } & \multicolumn{5}{l|}{ ROE } \\
\cline { 2 - 7 } & Coeff. & t-value & Sig. & Coeff. & t-value & Sig. \\
\hline Constant & 264.68 & 0.455603 & 0.65277 & -102.984 & -4.25645 & $0.00027^{* *}$ \\
\hline $\begin{array}{l}\text { Pre-Provision } \\
\text { Profit / } \\
\begin{array}{l}\text { Total Loans and } \\
\text { Advances }\end{array}\end{array}$ & -20.364 & -0.21432 & 0.83210 & 3.878074 & 0.980017 & 0.33685 \\
\hline $\begin{array}{l}\text { Loan to Asset } \\
\text { Ratio }\end{array}$ & 2052.7 & 0.556149 & 0.58325 & 114.277 & 0.743449 & 0.46442 \\
\hline $\begin{array}{l}\text { Capital } \\
\text { Adequacy Ratio }\end{array}$ & 12.281 & 0.452407 & 0.65503 & 0.347091 & 0.307015 & 0.76148 \\
\hline $\begin{array}{l}\text { Advances/loan } \\
\text { funds }\end{array}$ & -1.8559 & -0.25224 & 0.80300 & 1.072541 & 3.500211 & $0.00184^{* *}$ \\
\hline $\begin{array}{l}\text { Credit/ Deposit } \\
\text { Ratio }\end{array}$ & -2.7691 & -0.50548 & 0.61783 & -0.0024 & -0.01051 & 0.99170 \\
\hline
\end{tabular}

** Significant at $1 \%$ level

Source: Author's own source based on collected data

From table 7 the beta coefficients of both models can be observed. From the model, it can be seen that Return on Assets as a measure of profitability cannot be explained by credit risk because none of the $\mathrm{p}$-values shows a statistically significant relationship. However, in case of return on equity as the profitable measure, the p-values of Advances over Loan Funds show that there is a statistically significant relationship between this variable and return on Equity whereas rest of the variables like Pre-Provision Profit to 
Total Loans and Advances, Loan to Asset Ratio, Capital Adequacy Ratio and Credit to Deposit Ratio shows very weak relationship with Return of Equity as well as with Return on Assets. The null hypothesis "H0: Credit risk has no significant relationship with profitability of banks listed on the national stock exchange" shall be rejected in ROE model and accepted in the case of ROA model.

\section{Conclusion}

The objective of this study is to assess the impact of credit risk on the profitability of banks listed in the national stock exchange of India. To analyze the relationship between credit risk and profitability of banks secondary data was collected for six banks three from public sector and three from private sector. $\mathrm{ROE}$ and ROA are used as indicators to measure the profitability of banks Based on the financial information of 2009 to 2017. The time series data passes through the multicollinearity test and proved that it does not exist in the data as none of the VIF values for independent variables is higher than 10 . The result of unit root test was also checked to identify the stationarity of series. All the series are stationary at logarithmic first difference. Also, from the regression results, the value of Durbin-Watson statistic was checked which is around 2, which shows that there is no evidence of positive first-order serial correlation. Hence, there is no autocorrelation in credit risk variables. So, it is concluded that the values of the respective credit risk variables in one period did not depend on their values in another period. This study concludes that credit risk, as calculated from Pre-Provision Profit to Total Loans and Advances, Loan to Asset Ratio, Capital Adequacy Ratio, Credit to Deposit Ratio and Advances over Loan Funds have a non-significant relationship with profitability measured by Return on Assets whereas there is significant relationship exist between Advances over Loan Funds and profitability measured by Return on Equity. The study found model of ROE is better explained through the selected variables than the model of ROA. Also the results of the regression analysis show that there exist a negative correlation between credit upon deposit ratio and return on equity. As per the current study, the Indian banks has to keep check on advances upon total funds ratio, as it was found most significant factor impacting the profitability of Indian banks.

\section{Acknowledgement}

The authors are thankful to the anonymous referees of the journal for their handy 
suggestions to improve the quality of the article.

\section{Declaration of Conflict of Interest}

The authors declared no potential conflicts of interest with respect to the research, authorship, and/or publication of this article.

\section{Funding}

The author received no financial support for the research, authorship, and/or publication of this article.

\section{References}

[1] https://gomedici.com/8-risks-in-the-banking-industry-faced-by-every-bank/

[2] Poudel, R. P. S. (2012). The impact of credit risk management on financial performance of commercial banks in Nepal. International Journal of arts and commerce, 1(5), 9-15.

[3] Adekunle, O., Alalade, S. Y., Agbatogun, T., \& Abimbola, C. (2015). Credit Risk Management and Financial Performance of Selected Commercial Banks in Nigeria. Journal of Economic \& Financial Studies, 3(01), 01-09.

[4] Alshatti, A. S. (2015). The effect of credit risk management on financial performance of the Jordanian commercial banks. Investment Management and Financial Innovations, 12(1), 338-345.

[5] Karugu, B. M., \& Ntoiti, J. (2015). Effect of credit risk management practices on profitability of listed commercial banks at Nairobi securities exchange in Kenya. Journal of Economics and Finance, 6(5), 92-96.

[6] Makori, O. G. (2015). Effects Of Credit Risk Management Practices On Profitability Of Deposit Taking Sacco'S In Nairobi County (Doctoral dissertation, The Management University of Africa).

[7] Muhamet, A., \& Arbana, S. (2016). The Effect of Credit Risk Management on Banks' Profitability in Kosovo. European Journal of Economic Studies, (4), 492-515.

[8] Ndoka, S., \& Islami, M. (2016). The Impact of Credit Risk Management in the Profitability of Albanian Commercial Banks During the Period 20052015. European Journal of Sustainable Development, 5(3), 445-452. 
[9] Annor, E.S. \& Obeng, F. S. (1917) Impact of Credit Risk Management on the Profitability of Selected Commercial Banks Listed on the Ghana Stock Exchange, Journal of Economics, Management and Trade, 20 (2): 1-10.

[10] Kutum,I., (2017) The Impact of Credit Risk on the Profitability of Banks Listed on the Palestine Exchange. Research Journal of Finance and Accounting Vol.8, No.8,page 136-141

[11] Ishak, I., Ismail, N., Razali, N. A., Bakar, R., \& Ramlan, H., (2018) The Effects of Credit Risk on the Profitability of Commercial Banks in Afghanistan, The Journal of Asian Finance, Economics and Business, Volume 8 Issue 7, Pages.477-489.

[12] Hallunovi, A., \& Berdo, M. (2018). The Relationship between Risk Management and Profitability of Commercial Banks in Albania. Asian Themes in Social Sciences Research, 1(2), 44-49.

[13] Muhammad, B., Khan, S., \& Xu, Y. (2018). Understanding risk management practices in commercial banks: The case of the emerging market. Risk Governance and Control: Financial Markets \& Institutions, 8 (2), 54-62. 